\title{
ENCHENTES INESPERADAS? VULNERABILIDADES E POLÍTICAS PÚBLICAS EM RIO DO SUL - SC, BRASIL $^{1}$
}

\section{UNEXPECTED FLOODING? VULNERABILITIES AND PUBLIC POLICIES IN RIO DO SUL - SC, BRAZIL}

\author{
Marcos Aurélio Espíndola* \\ Eunice Sueli Nodari**
}

\begin{abstract}
Resumo: O principal objetivo do artigo é analisar as principais enchentes ocorridas no município de Rio do Sul, situado no Vale do Rio Itajaí-Açu, no Estado de Santa Catarina, Brasil. O processo de ocupação populacional da região pode ser considerado como um dos grandes responsáveis pela recorrência das inundações urbanas. Serão discutidas as enchentes mais significativas que afetaram a população causando danos reversíveis e irreversíveis, de cunho material, simbólico e mesmo emocional. As decisões tomadas como políticas públicas com o intuito de conter/minimizar novas ocorrências também mereceram uma análise. E por fim, através desta revisão pretendeuse preencher as lacunas deixadas pelas pesquisas que tratam dos desastres na região do Vale do Itajaí-Açu, que, em sua maioria se dedicam as cidades do Médio e Baixo Vale.
\end{abstract}

Palavras-chave: Rio do Sul. Enchentes. Desastres ambientais. Políticas Públicas.

\footnotetext{
* Pós-doutorando no projeto Desastres ambientais e políticas públicas em Santa Catarina nos séculos XIX, XX e início do presente século, junto ao Programa de Pós-Graduação Interdisciplinar em Ciências Humanas da Universidade Federal de Santa Catarina (UFSC). E-mail: marcredriver@gmail.com

** Professora nos Programas de Pós-Graduação em História e de Pós-Graduação Interdisciplinar em Ciências Humanas da Universidade Federal de Santa Catarina (UFSC). Coordenadora do projeto Desastres ambientais e políticas públicas em Santa Catarina nos séculos XIX, XX e início do presente século. E-mail: eunice@cfh.ufsc.br
} 


\begin{abstract}
The main purpose of this article is to analyze the major flooding that occurred in the municipality of Rio do Sul situated in the Valley of the Itajaí-Açu River, in the State of Santa Catarina, Brazil. The process of human occupation of the region can be considered as one of the great responsible for the recurrence of urban flooding. It will be discussed the most significant floods that affected the population causing reversible and irreversible material, symbolic and even emotional damages. Decisions adopted as public policy in order to contain or minimize new occurrences also deserved a review. And finally through this review an effort was made to fill the gaps left by following researches dealing mainly with the cities located in the Medium and Low Valley of the Itajaí-Açú River.
\end{abstract}

Keywords: Rio do Sul. Flooding. Environmental disasters. Public Policies.

\title{
INTRODUÇÃO
}

O Vale do Rio Itajaí-Açu situa-se no Nordeste do Estado de Santa Catarina. A bacia hidrográfica que o constitui é a maior do Estado, ocupando, aproximadamente, $15.000 \mathrm{~km}^{2}$ (Figura 1). Os Rios Itajaí do Sul, Itajaí do Oeste e Itajaí do Norte, formadores da bacia, descem a partir de suas nascentes, no Planalto Catarinense traçando cursos tortuosos e de alta declividade, que afluem, em direção aos Rios Itajaí-Açu e Itajaí-mirim; os quais se unem, para formar o estuário que separa os municípios de Itajaí e Navegantes em sua desembocadura, no Litoral Norte de Santa Catarina. A região apresenta grande importância econômica abrigando, além das referidas cidades portuárias, polos industriais de relevo; como Blumenau, Rio do Sul e Brusque. A Bacia sustenta grande área de drenagem, correspondente $\mathrm{a} 3 / 4$ da área total das bacias litorâneas de Santa Catarina. 
Figura 1: Localização da Bacia do Itajaí em Santa Catarina

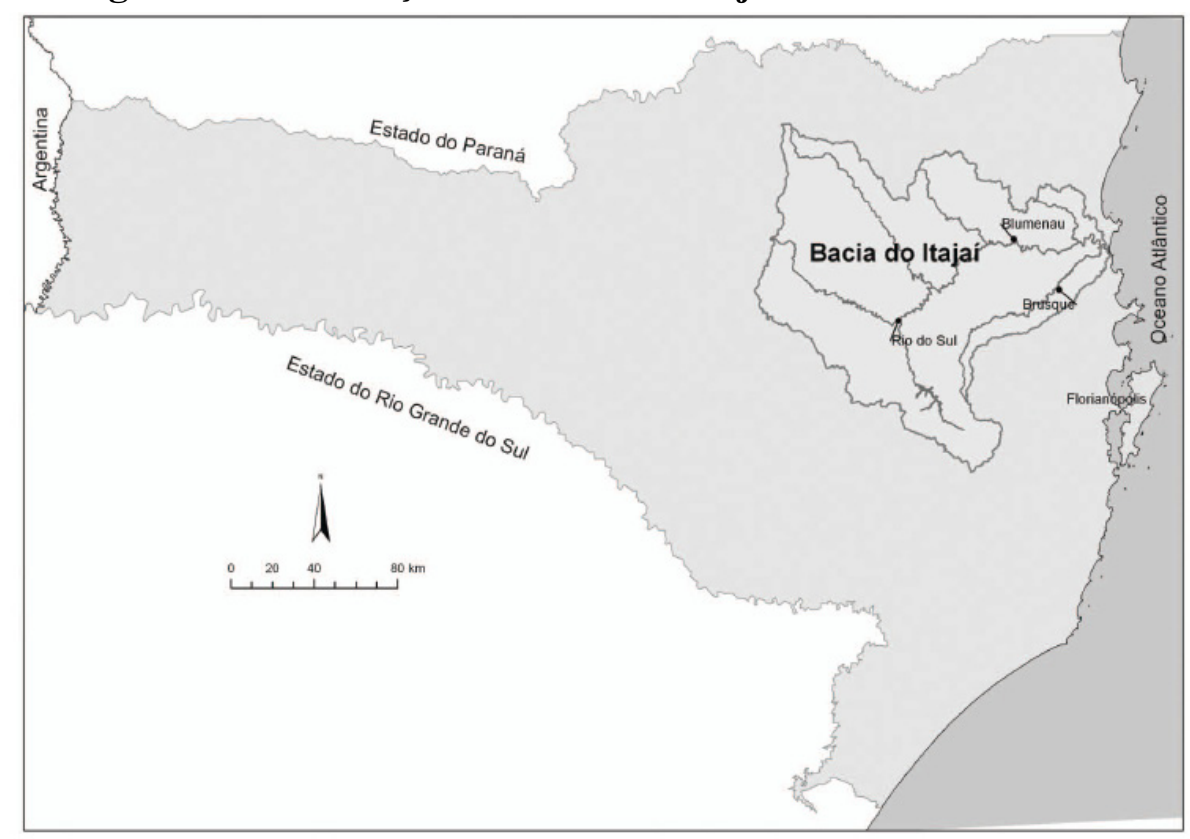

Fonte: FRANK; SEVEGNANI, 2009.²

As características naturais do Vale do Itajaí resultam de uma gama de interações de caráter geológico e climático que moldaram as

[...] encostas muito inclinadas, extremamente dobradas, frequentemente entalhadas em forma de ' $\mathrm{V}$ ' fechado e geralmente associadas a pequenas e estreitas várzeas em torno de ribeirões e rios, sujeitas às inundações frequentes. Na paisagem constata-se a presença de morros entremeio às planícies próximas ao oceano Atlântico, em Navegantes e Itajaí, tornando-se mais numerosos em direção a Luis Alves, Ilhota, Gaspar, Blumenau, Brusque e a outros municípios, gerando a bucólica paisagem do verde vale do Itajaí. ${ }^{3}$

Conhecer as características das encostas é de vital importância, pois assim, pode-se quantificar o fluxo do escoamento das precipitações e antever possibilidades das trajetórias dos deslizamentos e corridas de lama e detritos.

Por formar-se em áreas mais elevadas do que os demais sistemas hídricos, é comum ocorrerem rápidos e, muitas vezes, violentos deflúvios em direção ao litoral fazendo com que boa parte das enchentes, daí resultantes, transforme-se em catástrofes ambientais de certa magnitude. Este se constitui hoje no problema ambiental fulcral da região que, embora ocorra desde o início da colonização, vêm tornando-se cada vez mais grave conforme avança 
o desmatamento, com a ocupação das margens e mau uso do solo que leva à erosão do mesmo e ao assoreamento dos leitos dos rios.

Além do mais, a posição geográfica do Vale do Itajaí favorece a entrada dos ventos de sudeste e nordeste, que trazem consigo a umidade, proveniente do oceano em direção ao continente. Tal condição climática, quente e úmida, favorece densas precipitações, as quais costumam concentrar-se nas estações da primavera e do verão, influenciadas, também, pelo fenômeno El Niño/La Niña. Tais fatores contribuem para constituir o Vale do Itajaí como um ambiente propício à repetição e recrudescimento dos desastres ambientais. Uma região que sempre apresentou inundações, mas, que hoje, com a transformação acarretada pela ação antrópica, tem grande parte de seu território sujeito aos riscos destes desastres.

Tais transformações na paisagem são fontes históricas de extrema relevância. A cobertura vegetal do Vale do Rio Itajaí-Açu, foi transformada em virtude das condições climáticas e, principalmente, da ocupação humana.

Originalmente o vale possuía uma cobertura de Floresta Ombrófila Densa. ${ }^{4}$ No entanto, a intensiva exploração dos recursos vegetais, provindos da floresta, transfigurou a paisagem sem considerar e respeitar as características do ambiente e suas limitações, para o provimento da reprodução sociometabólica continuada, das populações que foram se instalando nas margens dos rios da bacia.

Desta forma, mostra-se manifesto que, o modelo de ocupação territorial é determinante na ocorrência dos desastres na região, o que deve ser ponto de partida para qualquer referência a eles. Torna-se, assim, necessário analisarmos mais demoradamente, a ocupação territorial do Vale do Rio Itajaí-Açu.

\section{FORMAÇÃO E OCUPAÇÃO TERRITORIAL DO VALE DO ITAJAÍ}

Por tratar-se da maior bacia, inteiramente catarinense, o Rio Itajaí-Açu, mantém suma importância no contexto hídrico estadual. Este rio é formado na região central do município de Rio do Sul, pela confluência dos Rios Itajaí do Oeste, originário da microrregião de Taió e Itajaí do Sul, proveniente da microrregião de Ituporanga. Torna-se, a partir de então, como Rio Itajaí-Açu, o principal elo entre o Alto Vale e o Litoral, chegando à Itajaí, onde aflui para o Rio Itajaí-mirim e passa a se chamar somente Rio Itajaí.

Em sua extensão de cerca de $190 \mathrm{~km}$, o curso do rio divide-se em Alto, Médio e Baixo e tem, seus afluentes são: como principais afluentes, os Rios Itajaí do Norte, Benedito, Testo, Garcia e Itajaí-mirim. As características topográficas do rio fazem com que seus perfis longitudinais sejam bastante acidentados, apresentando cursos tortuosos, entremeados por várias corredeiras, resultando, assim, em declividades de linha d'água muito altas. 
A vegetação que vicejava no Vale do Rio Itajaí era bastante diversificada, com predominância da floresta ombrófila densa, a qual ocupava quase a sua totalidade. No entanto, a agricultura, a dinâmica urbana e o ciclo exploratório da madeira, modificaram a condição da cobertura vegetal da Bacia do Itajaí, restando pouco da floresta primitiva.

A formação populacional do Vale do Itajaí deu-se por imigrantes, dentre sua maioria, alemães e italianos. Já haviam habitantes no vale antes da chegada dos europeus, que eram as populações nativas Xokleng, que ocupavam, sazonalmente a região, e, por se tratar de um grupo extrativista, deslocavam-se conforme as estações do ano e a oferta de alimentos.

Em meio aos conflitos com os nativos, os colonos, foram, aos poucos ocupando as regiões do Baixo, do Médio e do Alto Vale do Rio Itajaí-Açu. Estas populações não só estabeleceram a tônica cultural da região, mas também a modificaram, ao intervir de forma culturalmente determinada, sobre o ambiente original que encontraram.

A imigração de europeus foi marcada pela utilização dos rios e córregos, para o escoamento da produção de produtos agrícolas e manufaturas das colônias. Neste contexto, para o estabelecimento dos grupos, era essencial a proximidade com algum curso d'água. Assim, de certo modo, os desastres ambientais da região são tragédias anunciadas, em função da ocupação irregular das áreas de risco. $\mathrm{O}$ evento das fortes chuvas é natural, mas os desastres foram socialmente construídos no processo de ocupação e aproveitamento dos recursos naturais.

Os problemas originaram-se de fatores predominantes de caráter diverso, conforme a região. No alto Vale, a cobertura vegetal foi sendo paulatinamente destruída, dando lugar à atividade agropecuária. Já no Médio Vale a urbanização desenfreada, principalmente nas áreas de encostas, aparece como dilema fundamental, enquanto, na zona da foz, além da ocupação desordenada das encostas, produziu-se um intenso nó ambiental, com a extração de areia e a consequente intensificação do processo de erosão das margens do rio.

Quanto à demanda e à qualidade dos recursos hídricos, as condições historicamente constituídas pela ocupação, concentraram-se em fatores definidos pela urbanização, disseminada em diversas cidades de porte médio da região, pela intensa industrialização em municípios como Blumenau, Itajaí, Brusque e Rio do Sul, e extensas áreas agrícolas, principalmente naquelas ocupadas pelo cultivo do arroz-irrigado, que repartem a água disponível com o consumo urbano e a atividade industrial. Quanto à qualidade, a água da bacia sofre os efeitos dos mesmos fatores, que no caso tornam-se fatores de degradação. A região da foz, além de receber o acúmulo de material poluente depositado nos rios por todo o seu curso, ainda sofre com a alta salinidade, que se tornou o maior problema para o abastecimento dos municípios de Itajaí e Navegantes, tornando-se mote nas campanhas políticas dos últimos anos, mais do que os óbices ligados às enchentes. 
O desmatamento descontrolado, principalmente durante o ciclo da madeira, compactou o solo. As práticas agrícolas dos imigrantes eram inadequadas às condições de clima e solo da bacia. As queimadas e a exigência de constante aumento na produtividade provocaram maior pressão sobre os recursos naturais, e; como resultados, obteve-se a destruição de florestas, a erosão e a perda da produtividade do solo, o assoreamento dos cursos d'água e o maior escoamento destas. ${ }^{5}$

Intervenções ambientalmente irresponsáveis cada vez mais frequentes em toda a região, alterando o leito e o curso dos rios ou destruindo as matas ciliares, tornaram-se alarmantes, provocando mudanças no seu regime normal, como o aumento da velocidade da água e o consequente assoreamento com pedras, o alagamento das curvas remanescentes o retorno ao curso original em locais com intervenções nas curvas, entre outras.

A falta de visão das políticas públicas de planejamento, prevenção e compensação relativas a estes problemas ficou explicita na declaração do exgovernador do Estado de Santa Catarina, Sr. Esperidião Amin Hellou Filho, que no ano da catastrófica enchente de 1983 era o então governador do Estado de SC atestando "a não vulnerabilidade do estado de Santa Catarina, frente às cheias"6 e afirmando "que não vê Santa Catarina vulnerável às cheias e que as cidades é que invadiram áreas potencialmente inundáveis muito próximas aos rios". ${ }^{7}$

Infelizmente, o que foi realizado através do Governo Estadual foram apenas obras estruturais de engenharia, controlando fisicamente os rios como: barragens, comportas, retificações, canalizações. O processo de formulação de tais medidas na Bacia do Itajaí teve início em 1957, quando aconteceram cheias com altas cotas em Blumenau.

Estudos da década de 1950 justificavam a implantação das barragens. Os de caráter geoeconômico mostravam que os fatores energia e transporte, constituíam os problemas gerais que impediam o desenvolvimento da Bacia do Itajaí. Além disto, evidenciaram que, o progresso das transações comerciais na região foi maior do que o verificado em outros centros mais bem desenvolvido da União, comprovando o benefício econômico de investimentos em obras para uso múltiplo dos rios da bacia.

Em 1957, um decreto do Presidente da República nomeou um grupo de trabalho, o qual foi encarregado de concluir projetos e executar obras. As principais obras de contenção assim indicadas, executadas pelo extinto Departamento Nacional de Obras e Saneamento (DNOS) foram as barragens Oeste, em Taió; Sul, em Ituporanga e Norte, objetivando resolver o problema das enchentes, principalmente em Blumenau. ${ }^{8}$

Infelizmente os locais onde podiam ser construídas barragens naquele vale não possibilitavam controlar a maior parte da bacia contribuinte. Terminou sendo necessário 
complementar as barragens com dragagem do rio Itajaí a jusante de Blumenau, para abaixar satisfatoriamente o nível d'água naquela cidade. Infelizmente o DNOS foi extinto antes de completar esta dragagem, que só foi executada entre as cidades de Blumenau e Gaspar, sem beneficiar esta última cidade nem a área a jusante da mesma. ${ }^{9}$

Mais recentemente, após as cheias de 2008, outras modificações estruturais, como o canal retificador do rio Itajaí-Mirim, no município de Itajaí, foram executadas. No entanto, todas estas obras mostraram-se insuficientes para conter as águas dos rios, na tentativa de impedir a ocorrência de novas enchentes na maioria dos municípios do Vale do Itajaí.

Outras medidas, como a instalação de um sistema de alerta antecipado, da estação de telemetria e de um radar meteorológico, não se mostraram, até o momento, eficientes, seja por não terem sido implementadas adequadamente, seja por restringirem-se a região de Blumenau.

Porém, é fato que, todos estes desastres são decorrentes da má utilização do solo pelos habitantes das regiões atingidas, de tal forma a tornar as obras, realizadas e a realizar, sempre insuficientes, enquanto se restringirem às intervenções estruturais. Somente através da conscientização social e por meio de uma serie de intervenções não estruturais, haveria a possibilidade de não repetirem-se tais desastres ambientais.

\section{OCUPAÇÃO DO MUNICÍPIO DE RIO DO SUL}

Em 1850, com a fundação de Blumenau, fez-se necessária à abertura de uma ligação desta cidade até Curitibanos, já que o caminho para o Planalto era imensamente maior pelo Litoral. Até então, a área que entremeava estas duas regiões não apresentava qualquer povoamento, exceto àquele constituído pelos indígenas seminômades Xokleng. Fez-se, assim, a necessidade, comercial e política, de sua ocupação como elo comunicante.

O povoado de Braço do Sul, depois batizado de Nova Aliança, tornado distrito sob administração blumenauense em 1912, destinou-se a fazer este papel, já que estabelecido em localização privilegiada para isto. Não só foi erguido a meio caminho entre Blumenau e Lages, como permitiu aproveitar o transporte fluvial, pois os rios Itajaí do Sul e Itajaí do Oeste confluem dentro de seu território.

Assim como no restante do Vale do Rio Itajaí, sua ocupação deu-se através de colonos de origem alemã e italiana, advindos, na sua maioria, do município de Blumenau, os quais logo entraram em conflito com os Xokleng, cizânia que durou até o estabelecimento do Posto Indígena Duque de Caxias, em $1914 .{ }^{10}$ 
Após a emancipação do distrito, constituiu-se, em 1930, o município de Rio do Sul, que logo se tornou o centro dinâmico do Alto Vale, centralizando a extração madeireira. A localidade, desde o início, sofreu com as cheias da confluência de rios, que passam por grande maioria do território da cidade. Mas, as formas de ocupação e uso do solo a eles adjacente reforçou este fato, transformando as cheias em desastres ambientais.

Historicamente a cidade de Rio do Sul se desenvolveu, assim como outras tantas, as margens dos rios. Os primeiros núcleos populacionais da região ignoraram a base topográfica e hidrográfica local. Em Rio do Sul, é possível observar, nos últimos anos, pelas edificações e pelo mercado imobiliário, o deslocamento das atividades urbanas em direção a áreas mais altas, posteriormente à sua instalação inicial. Isto se deu, principalmente, após as enchentes de 1983/84, as quais alteraram profundamente o panorama urbanístico da cidade, provocando a abertura de diversos bairros e transferências populacionais das áreas mais altas para as mais baixas e vice-versa. Em geral, os membros das classes mais abastadas transferiram-se para áreas mais altas, abrigadas das enchentes, ocorrendo o inverso com a população de baixa renda.

É evidente, na forma de ocupar o espaço, a despreocupação com os rios, para os quais seus habitantes sempre davam as costas. Os rios Itajaí do Oeste, do Sul e Açu várias vezes saíram de seus leitos, inundando margens e causando alagamentos em residências e nos bairros mais baixos como Santana, Canoas e Sumaré, onde aquelas já se adaptavam a dois pisos.

Na década de 1970, a implantação da BR 470 eleva a condição de polo regional de Rio do Sul. "Neste período, o índice de crescimento da cidade chega a 2,78 e nos anos 80 , com o esgotamento do ciclo da madeira, associado à crise econômica do país, acontece o declínio econômico". ${ }^{11}$

Assim, a cidade, ao mesmo tempo, se adapta aos padrões urbanísticos da era da informação, criando instrumentos metodológicos, jurídicos e legislativos, que amarraram o sistema de planejamento urbano à meta de atingir moldes industriais. $^{12}$

\section{AS CATASTRÓFICAS ENCHENTES OCORRIDAS NO MUNICÍPIO DE RIO DO SUL}

É de fácil constatação a determinação, constituída pelo encontro dos Rios Itajaí do Sul e do Oeste, sobre a história e a vida da população Riosulense. O Rio Itajaí-Açu e seus afluentes, várias vezes saíram de seus leitos, inundando margens e áreas com cotas mais baixas.

Enchentes, de maiores ou menores proporções, são processos naturais. No entanto, os fatores não naturais que influenciam na ocorrência dos desastres, são causados por intervenções antrópicas, como a expansão urbana 
descontrolada e dissociada do meio ambiente. A dinâmica de intervenção humana nos rios, com a instalação da cidade nas várzeas, contribuiu para a formação de superfícies compactadas, as quais aumentam o volume de água superficial e reduzem a capacidade de infiltração, modificando o padrão de ação dos agentes naturais, quando da formação de situações de emergência. O descumprimento de legislações voltadas a edificações e infraestruturas físicas sem conservação e manutenção, são outros fatores a serem apontados na constituição dos panoramas de desastre.

O estudo da alteração da forma urbana de Rio do Sul vem buscar uma explicação das relações estabelecidas entre o espaço natural e a cidade, que nele se instalou, interpretando vetores de crescimento territoriais vivenciados, o que visa aumentar conhecimentos para auxiliar no planejamento urbano, já que as enchentes, ameaças em potencial, continuam sendo tema pouco estudado no Brasil.

Torna-se impossível, nos dias de hoje, trabalhar com construção civil em Rio do Sul desconsiderando a variável enchente. A possibilidade ou não de uma enchente atingir uma edificação, redefine a forma de ocupação volumétrica e seu valor de mercado.

As enchentes sempre foram percebidas como um sério problema, embora afetando, mais diretamente, os moradores das áreas de cotas mais baixas, onde residiam pessoas com menor poder aquisitivo. Pressupõem-se, para estas pessoas, maior dificuldade em acessar recursos e força política no sentido de viabilizar ações globais de prevenção e compensação. O caminho indicado ao longo do tempo seria o de erguer ao máximo as edificações para que não fossem tão seriamente atingidas. A responsabilidade em discutir a questão parecia problema exclusivo do poder público, sempre envolvido nas situações de crise. Mas isto somente aconteceu a partir de 1983, quando a magnitude do fenômeno atingiu um contingente populacional bem maior.

Na Tabela 1 observa-se as principais enchentes no Vale do Itajaí, no século XIX. De acordo com os dados do Centro de Operação do Sistema de Alerta (CEOPS) da Universidade Regional de Blumenau (FURB) o município de Rio do Sul, assim como outros municípios não apresentaram registros de enchentes, apenas no município de Blumenau foram registrados 12 enchentes. 
Tabela 1 - Picos de Enchentes Registrados na Bacia do Rio Itajaí-Açu no século XIX

\begin{tabular}{|c|c|c|c|c|c|c|c|c|}
\hline Ano & Data & Blumenau & Brusque* & Gaspar* & Ibirama* & Indaial & Rio do Sul* & Timbó \\
\hline 1852 & $29 / 10$ & $16,3 \mathrm{~m}$ & & & & $8,3 \mathrm{~m}$ & & \\
\hline 1855 & $20 / 11$ & $13,3 \mathrm{~m}$ & & & & & & \\
\hline 1852 & $29 / 10$ & $16,3 \mathrm{~m}$ & & & & $8,3 \mathrm{~m}$ & & \\
\hline 1855 & $20 / 11$ & $13,3 \mathrm{~m}$ & & & & & & \\
\hline 1862 & $20 / 11$ & $9 m$ & & & & & & \\
\hline 1864 & $17 / 09$ & $10 \mathrm{~m}$ & & & & & & \\
\hline 1868 & $27 / 11$ & $13,3 \mathrm{~m}$ & & & & & & \\
\hline 1870 & $11 / 10$ & $10 \mathrm{~m}$ & & & & & & \\
\hline 1880 & $23 / 09$ & $17,1 \mathrm{~m}$ & & & & $8,7 \mathrm{~m}$ & & \\
\hline 1888 & $23 / 09$ & $12,8 \mathrm{~m}$ & & & & & & $10 \mathrm{~m}$ \\
\hline 1891 & $18 / 06$ & $13,8 \mathrm{~m}$ & & & & & & \\
\hline 1898 & $1 / 05$ & $12,8 \mathrm{~m}$ & & & & & & \\
\hline
\end{tabular}

* Não foram auferidos registros nestes municípios. Fonte: FURB. Centro de Operação do Sistema de Alerta (CEOPS). ${ }^{13}$

Já no século XX há registros de inundações em outros municípios como se observa na tabela 2. No ano de 1911 o município de Rio do Sul atingiu a cota de $12,8 \mathrm{~m}$. Nas décadas seguintes houve um número expressivo de enchentes na Bacia do Rio Itajaí-Açu. Vários municípios sofreram com inundações. As décadas que apresentaram maior número de registro foram as de 1950, 1970 e 1980. Mas sem dúvida em termos de proporções a década de 1980 foi um marco na memória das enchentes na região. As enchentes de 1983 e 1984 tiveram um volume significativo. Em Rio do Sul a cota chegou a 15,58m em julho de 1983 e em agosto de 1984 a 12,8 metros. 
Tabela 2 - Picos de Enchentes Registrados na Bacia do Rio Itajaí-Açu no século $X X$

\begin{tabular}{|c|c|c|c|c|c|c|c|c|}
\hline Ano & Data & Blumenau & Brusque* & Gaspar* & Ibirama & Indaial & Rio do Sul & Timbó \\
\hline 1900 & $2 / 10$ & $12,8 \mathrm{~m}$ & & & & & & \\
\hline 1911 & $29 / 05$ & $16,9 \mathrm{~m}$ & & & & $8,5 \mathrm{~m}$ & $12,2 \mathrm{~m}$ & $9,3 \mathrm{~m}$ \\
\hline 1911 & $20 / 06$ & $9,86 \mathrm{~m}$ & & & & & & \\
\hline 1923 & $14 / 05$ & $9 \mathrm{~m}$ & & & & & & \\
\hline 1925 & $14 / 01$ & $10,3 \mathrm{~m}$ & & & & $5,32 \mathrm{~m}$ & & \\
\hline 1926 & $9 / 11$ & $9,5 \mathrm{~m}$ & & & & & & \\
\hline 1927 & $18 / 06$ & $12,3 \mathrm{~m}$ & & & & $6,55 \mathrm{~m}$ & $10 \mathrm{~m}$ & \\
\hline 1928 & $15 / 08$ & $11,76 \mathrm{~m}$ & & & & $6 \mathrm{~m}$ & $8,13 \mathrm{~m}$ & \\
\hline 1928 & $2 / 05$ & $10,82 \mathrm{~m}$ & & & & & $8,63 \mathrm{~m}$ & \\
\hline 1931 & $18 / 09$ & $10,8 \mathrm{~m}$ & & & $4,48 \mathrm{~m}$ & $5,5 \mathrm{~m}$ & $7,54 \mathrm{~m}$ & $5,3 \mathrm{~m}$ \\
\hline 1931 & $25 / 05$ & $10,8 \mathrm{~m}$ & & & $3,46 \mathrm{~m}$ & $5,7 \mathrm{~m}$ & $10,18 \mathrm{~m}$ & $5,4 \mathrm{~m}$ \\
\hline 1932 & $4 / 10$ & $9,85 \mathrm{~m}$ & & & & & & \\
\hline 1933 & $29 / 09$ & $11,65 \mathrm{~m}$ & & & $3,96 \mathrm{~m}$ & $5,7 \mathrm{~m}$ & $9,12 \mathrm{~m}$ & \\
\hline 1935 & $27 / 11$ & $11,4 \mathrm{~m}$ & & & & & $6,2 \mathrm{~m}$ & $6,5 \mathrm{~m}$ \\
\hline 1939 & $3 / 08$ & $11,2 \mathrm{~m}$ & & & & $5,8 \mathrm{~m}$ & $8,8 \mathrm{~m}$ & $4,5 \mathrm{~m}$ \\
\hline 1943 & $17 / 05$ & $10,25 \mathrm{~m}$ & & & & & & \\
\hline 1948 & $17 / 10$ & $11,8 \mathrm{~m}$ & & & $4,4 \mathrm{~m}$ & $5,9 \mathrm{~m}$ & $9 \mathrm{~m}$ & $6,1 \mathrm{~m}$ \\
\hline 1950 & $31 / 10$ & $9,1 \mathrm{~m}$ & & & $3,6 \mathrm{~m}$ & $4,72 \mathrm{~m}$ & $8,75 \mathrm{~m}$ & $3,1 \mathrm{~m}$ \\
\hline 1953 & $31 / 10$ & $9,4 \mathrm{~m}$ & & & $3,7 \mathrm{~m}$ & $4,9 \mathrm{~m}$ & $8,25 \mathrm{~m}$ & $4,8 \mathrm{~m}$ \\
\hline 1954 & $19 / 05$ & $9,3 \mathrm{~m}$ & & & $3,7 \mathrm{~m}$ & $4,69 \mathrm{~m}$ & $6,85 \mathrm{~m}$ & $4,7 \mathrm{~m}$ \\
\hline 1954 & $22 / 10$ & $12,88 \mathrm{~m}$ & & & $4,3 \mathrm{~m}$ & $6,1 \mathrm{~m}$ & $10,7 \mathrm{~m}$ & $5,45 \mathrm{~m}$ \\
\hline 1955 & $19 / 05$ & $10,36 \mathrm{~m}$ & & & $4,32 \mathrm{~m}$ & $5,26 \mathrm{~m}$ & $8,3 \mathrm{~m}$ & $5,3 \mathrm{~m}$ \\
\hline 1957 & $21 / 07$ & $9,1 \mathrm{~m}$ & & & $3,6 \mathrm{~m}$ & $4,65 \mathrm{~m}$ & $7,37 \mathrm{~m}$ & $4,9 \mathrm{~m}$ \\
\hline 1957 & $2 / 08$ & $10,4 \mathrm{~m}$ & & & $3,95 \mathrm{~m}$ & $5,22 \mathrm{~m}$ & $9,65 \mathrm{~m}$ & $3,6 \mathrm{~m}$ \\
\hline 1957 & $18 / 08$ & $12,86 \mathrm{~m}$ & & & $5,05 \mathrm{~m}$ & $6,48 \mathrm{~m}$ & $10,65 \mathrm{~m}$ & $5,4 \mathrm{~m}$ \\
\hline 1957 & $16 / 09$ & $9,24 \mathrm{~m}$ & & & $3,64 \mathrm{~m}$ & $4,64 \mathrm{~m}$ & $7,2 \mathrm{~m}$ & $3,6 \mathrm{~m}$ \\
\hline 1957 & $16 / 09$ & $9,24 \mathrm{~m}$ & & & $3,64 \mathrm{~m}$ & $4,64 \mathrm{~m}$ & $7,2 \mathrm{~m}$ & $3,6 \mathrm{~m}$ \\
\hline 1961 & $12 / 09$ & $10,1 \mathrm{~m}$ & & & $4,14 \mathrm{~m}$ & $5,08 \mathrm{~m}$ & $8,2 \mathrm{~m}$ & $3,1 \mathrm{~m}$ \\
\hline 1961 & $30 / 09$ & $9,4 \mathrm{~m}$ & & & & & & \\
\hline 1961 & $1 / 11$ & $12,18 \mathrm{~m}$ & & & $3,85 \mathrm{~m}$ & $5,46 \mathrm{~m}$ & $9,75 \mathrm{~m}$ & $6,5 \mathrm{~m}$ \\
\hline 1966 & $13 / 02$ & $9,82 \mathrm{~m}$ & & & $3,38 \mathrm{~m}$ & $5 \mathrm{~m}$ & 10 & $4,05 \mathrm{~m}$ \\
\hline 1969 & $6 / 04$ & $9,89 \mathrm{~m}$ & & & $4,1 \mathrm{~m}$ & $5,12 \mathrm{~m}$ & $7,45 \mathrm{~m}$ & $4,95 \mathrm{~m}$ \\
\hline 1971 & $10 / 06$ & $10,1 \mathrm{~m}$ & & & $4,46 \mathrm{~m}$ & $5,32 \mathrm{~m}$ & $7 \mathrm{~m}$ & $3,5 \mathrm{~m}$ \\
\hline 1972 & $29 / 08$ & $11,07 \mathrm{~m}$ & & & $4,1 \mathrm{~m}$ & $5,5 \mathrm{~m}$ & $9,15 \mathrm{~m}$ & 4 \\
\hline 1973 & $25 / 06$ & $11,05 \mathrm{~m}$ & & & $5 \mathrm{~m}$ & $5,76 \mathrm{~m}$ & $6,6 \mathrm{~m}$ & $4,9 \mathrm{~m}$ \\
\hline 1973 & $22 / 07$ & $9,1 \mathrm{~m}$ & & & $3,55 \mathrm{~m}$ & $4,74 \mathrm{~m}$ & $7,15 \mathrm{~m}$ & $5,6 \mathrm{~m}$ \\
\hline 1973 & $29 / 08$ & $12,24 \mathrm{~m}$ & & & $4,65 \mathrm{~m}$ & $6,1 \mathrm{~m}$ & $8,1 \mathrm{~m}$ & $6,28 \mathrm{~m}$ \\
\hline 1975 & $4 / 10$ & $12,4 \mathrm{~m}$ & & & $5,7 \mathrm{~m}$ & $6,34 \mathrm{~m}$ & $7,88 \mathrm{~m}$ & $6,07 \mathrm{~m}$ \\
\hline 1977 & $18 / 08$ & $9,25 \mathrm{~m}$ & & & $3 \mathrm{~m}$ & $4,96 \mathrm{~m}$ & $8,85 \mathrm{~m}$ & $2,9 \mathrm{~m}$ \\
\hline 1978 & $26 / 12$ & $11,45 \mathrm{~m}$ & & & $4,9 \mathrm{~m}$ & $5,94 \mathrm{~m}$ & $6,75 \mathrm{~m}$ & $5,5 \mathrm{~m}$ \\
\hline 1979 & $10 / 05$ & $9,75 \mathrm{~m}$ & & & $4,4 \mathrm{~m}$ & $5,32 \mathrm{~m}$ & $5,6 \mathrm{~m}$ & $5,15 \mathrm{~m}$ \\
\hline 1979 & $9 / 10$ & $10,2 \mathrm{~m}$ & & & $6,05 \mathrm{~m}$ & $5,64 \mathrm{~m}$ & $5,9 \mathrm{~m}$ & $4,7 \mathrm{~m}$ \\
\hline 1980 & $22 / 12$ & $13,02 \mathrm{~m}$ & & & $5,5 \mathrm{~m}$ & $7,1 \mathrm{~m}$ & $7,2 \mathrm{~m}$ & $6,46 \mathrm{~m}$ \\
\hline 1983 & $4 / 03$ & $10,35 \mathrm{~m}$ & & & $5,2 \mathrm{~m}$ & $5,58 \mathrm{~m}$ & $5,8 \mathrm{~m}$ & $5,1 \mathrm{~m}$ \\
\hline 1983 & $20 / 05$ & $12,46 \mathrm{~m}$ & & & $6,35 \mathrm{~m}$ & $6,72 \mathrm{~m}$ & $7,35 \mathrm{~m}$ & $6,7 \mathrm{~m}$ \\
\hline 1983 & $9 / 07$ & $15,34 \mathrm{~m}$ & & $11,67 \mathrm{~m}$ & $7,15 \mathrm{~m}$ & $7,76 \mathrm{~m}$ & $13,58 \mathrm{~m}$ & $8,7 \mathrm{~m}$ \\
\hline 1983 & $24 / 09$ & $11,5 \mathrm{~m}$ & & & $5,48 \mathrm{~m}$ & $6,06 \mathrm{~m}$ & $7,6 \mathrm{~m}$ & $5,55 \mathrm{~m}$ \\
\hline 1990 & $21 / 07$ & $8,82 \mathrm{~m}$ & & $7,28 \mathrm{~m}$ & $4,13 \mathrm{~m}$ & & $6,92 \mathrm{~m}$ & $5,7 \mathrm{~m}$ \\
\hline 1992 & $29 / 05$ & $12,8 \mathrm{~m}$ & & $9,92 \mathrm{~m}$ & $5,87 \mathrm{~m}$ & $7,12 \mathrm{~m}$ & $7,92 \mathrm{~m}$ & $9,75 \mathrm{~m}$ \\
\hline 1992 & $1 / 0$ & $10,62 \mathrm{~m}$ & & $8,58 \mathrm{~m}$ & $4,98 \mathrm{~m}$ & $6,14 \mathrm{~m}$ & $8,36 \mathrm{~m}$ & $6,16 \mathrm{~m}$ \\
\hline 1997 & $1 / 02$ & $9,44 \mathrm{~m}$ & & $7,48 \mathrm{~m}$ & $3,6 \mathrm{~m}$ & $5,49 \mathrm{~m}$ & $8,72 \mathrm{~m}$ & $6,2 \mathrm{~m}$ \\
\hline
\end{tabular}

* Não foram auferidos registros nestes municípios.

Fonte: FURB. Centro de Operação do Sistema de Alerta (CEOPS). Disponível em: $<$ http://ceops.furb.br/index.php?option=com_wrapper\&view=wrapper\&Itemid=42>. Acesso em: 23 mar. 2014. 
Nas primeiras décadas do século XXI a recorrência das enchentes no vale e especificamente no município de Rio do Sul é marcante como demonstram os dados dos picos de enchente da tabela 3. Em Rio do Sul, em outubro de 2001 observa-se uma cota de inundação de $9,1 \mathrm{~m}$. Após um intervalo de 9 anos, em maio de 2010 e em agosto e setembro de 2011, com as respectivas cotas de 8,76 e 12,98, o município novamente enfrentou sérios problemas com as enchentes.

Tabela 3 - Picos de Enchentes Registrados na Bacia do Rio Itajaí-Açu no século XXI

\begin{tabular}{ccccccccc}
\hline Ano & Data & Blumenau & Brusque & Gaspar & Ibirama & Indaial & Rio do Sul & Timbó \\
\hline 2001 & $1 / 10$ & $11,02 \mathrm{~m}$ & & $8,24 \mathrm{~m}$ & & $6,54 \mathrm{~m}$ & $9,1 \mathrm{~m}$ & $7,95 \mathrm{~m}$ \\
2008 & $24 / 11$ & $11,72 \mathrm{~m}$ & & & & & & $8,22 \mathrm{~m}$ \\
2010 & $26 / 05$ & $8,64 \mathrm{~m}$ & & & $4 \mathrm{~m}$ & & $6,92 \mathrm{~m}$ & $7,11 \mathrm{~m}$ \\
2011 & $31 / 08$ & $8,7 \mathrm{~m}$ & & & $3,81 \mathrm{~m}$ & $5,83 \mathrm{~m}$ & $8,76 \mathrm{~m}$ & $6,21 \mathrm{~m}$ \\
2011 & $9 / 09$ & $12,8 \mathrm{~m}$ & $10,21 \mathrm{~m}$ & $9,42 \mathrm{~m}$ & $4,97 \mathrm{~m}$ & $7,6 \mathrm{~m}$ & $12,98 \mathrm{~m}$ & $9,86 \mathrm{~m}$ \\
\hline
\end{tabular}

Fonte: FURG. Centro de Operação do Sistema de Alerta (CEOPS). Disponível em: <http:// ceops.furb.br/index.php?option $=$ com_wrapper\&view $=$ wrapper\&Itemid $=42>$. Acesso em: 23 mar. 2014.

Deve-se notar que no referido Vale, $52 \%$ destas enchentes aconteceram na Primavera; $28 \%$ no Outono; $13 \%$ no Inverno e $7 \%$ no Verão. As grandes enchentes de 1983 e 84 ocorreram excepcionalmente, como foi mencionado, no Inverno, uma das estações mais secas do ano.

De toda a forma, o padrão recorrente sempre foi o mesmo, com os desastres atingindo os sistemas habitacionais, produtivos, de transporte e de esgoto, como se pode auferir nos telegramas de Max Mayer, publicados em outubro de 1918, no Jornal República.

O temporal que desabou, há tres dias, causou grandes prejuízos materiaes no interior do Estado. As aguas innundaram algumas localidades, tendo na sua passagem levado pontes, pontilhões e boeiros. No Rio do Sul, os estragos foram bem regulares.A proposito, o sr. coronel Paulo Zimmermann, superintendente de Blumenau, recebeu hontem o seguinte telegrama: «Rio do Sul, 30. -Terrível enchente causando districto enormes prejuízos plantações e criações, principalmente estradas, destruindo boeiros desta freguezia. Diversas casas estão inundadas abandonadas pelos moradores, desde ante-hontem. $O$ transito nas estradas está interrompido, o que demonstra importancia dos estragos. As superstructuras de pontes, planchões e destroços correm aguas abaixo. Notícias trazidas pelos 
canoeiros informam destruição das pontes de Landerbach; Albertinos e outros. Consta que no Trombudo o temporal fez estragos. Urgente solicitar soccorros governo Saudações. Max Mayer, intendente. ${ }^{14}$

Infelizmente, segundo informações da Defesa Civil, são poucos os dados sobre enchentes catalogados antes de 1983. Até então, o meio mais profícuo de colher informações sobre os desastres eram as informações publicadas nos periódicos, nem sempre tão detalhadas e que pode ser observado nas notas do Jornal República, referindo-se à enchente de 1918 e 1928 na região: "O temporal que desabou há três dias causou grandes prejuízos materiais no interior do estado [...]". " "[...] Rio do Sul já subiu oito metros continuando a encher". ${ }^{15}$

Algumas áreas apresentam um índice maior de vulnerabilidade e são mais suscetíveis a enchentes, como os bairros Canoas, Barra do Trombudo, Santana e Budag.

Existem registros sobre enchentes desde 1851, quando se chegou a uma extraordinária cota d'água de 16,8 metros $^{16}$. Todavia, não foram encontradas maiores informações, a não ser a de que uma primitiva picada, erguida na época, foi destruída, o "picadão de Curitibanos, para fugir às inundações afastou-se do rio, conservando-se na parte mais alta do terreno adjacente". ${ }^{17}$

A década de 1920 (Figura 2) foi particularmente funesta para Rio do Sul. Em 1926, pelo interior do município, trombas d'água fizeram transbordar violentamente os ribeirões, levando os Rios Itajaí do Sul e do Oeste a despejar grandes massas d'água; e, no ano seguinte, novas trombas d'água fizeram com que as águas do Rio Itajaí do Sul aumentassem assustadoramente de volume, chegando a subir $75 \mathrm{~cm}$ por hora. ${ }^{18}$ Em 1928, "telegramas de Rio do Sul anunciavam que ali as águas haviam subido em 12 horas 8,20 metros. Segundo o jornal Der Urwaldsbote o maior volume de água desceu das regiões do Rio do Sul e do Rio do Oeste, onde as águas subiram 9,20 metros". ${ }^{19}$ 
Figura 2 - Foto da Enchente de 1927 em Rio do Sul

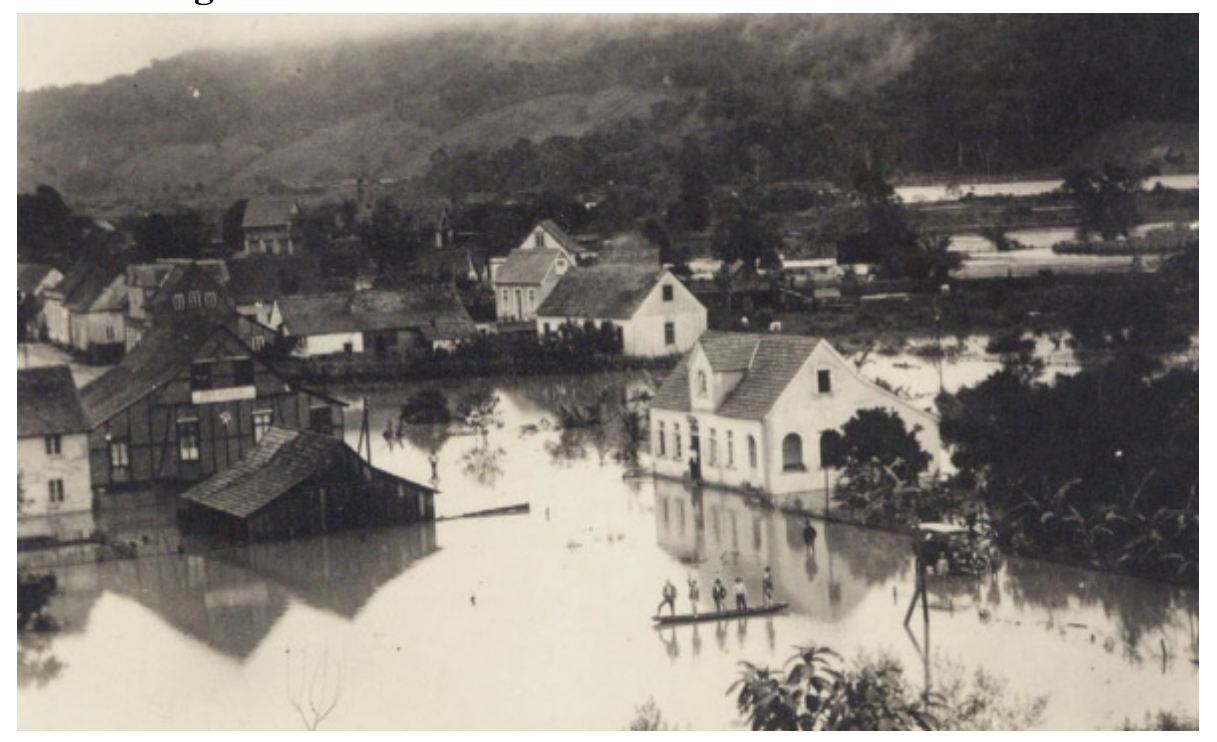

Fonte: Arquivo Particular Guthis Auto Peças. Disponível em: $<$ http://www. guthsautopecas.com.br/fotos2enc.html>. Acesso em 23 mar. 2014. ${ }^{20}$

Apesar de todos estes desastres, parece que nenhuma medida ou cautela, em relação ao uso dos rios e do solo, foi adotada. Rio do Sul continuou a aterrar várzeas, pois, quando a frequência das inundações é baixa, a população despreza o risco. A forma urbana de Rio do Sul continuou crescendo de costas para os rios e, como agravante, teve este modelo reproduzido nas cidades vizinhas.

Assim, em 31 de outubro de 1953, novamente "uma tromba d'água desaba sobre Rio do Sul [...]. Parte de um morro, na Rua Hermann Hering, deslizou atingindo uma residência, causando sérios prejuízos" ${ }^{21}$ e, em 1954, (Figura 3) “[...] Rio do Sul também foi duramente atingido, sendo altíssimos os prejuízos sofridos pela cidade e pelo interior do rico município da serra acima. As águas subiram até o nível de $11,88 \mathrm{~m} "{ }^{22}$ 
Figura 3 - Foto da Enchente em Rio do Sul (1954)

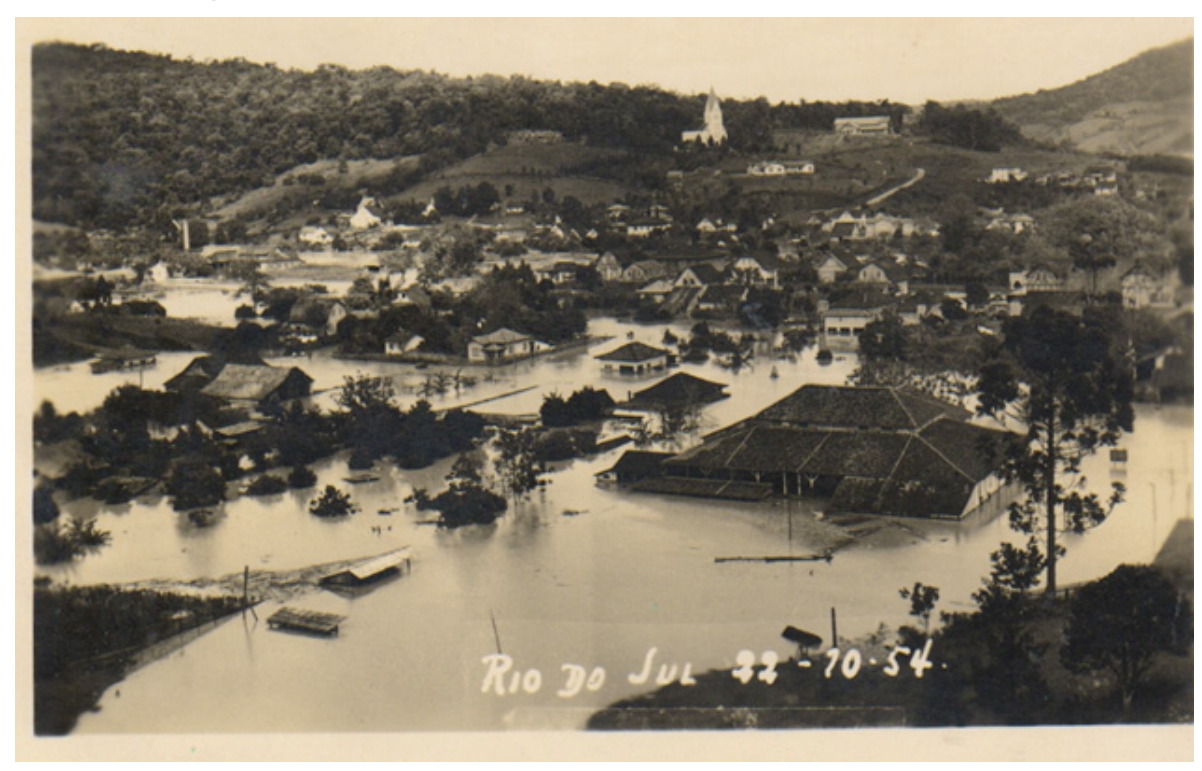

Fonte: Arquivo Municipal de Rio do Sul.

Ainda assim, foram, a partir de então, tomadas apenas medidas tímidas, de cunho científico, por meio do programa de Prevenção de Enchentes no Vale do Itajá́, ligado ao Departamento Nacional de Obras e Saneamento (DNOS). Mas não foi, sequer, criado um sistema de catalogação dos níveis dos rios em Rio do Sul, embora os dados científicos permitissem reunir, já em 1965, um Relatório de Enchentes do Vale do Itajaí.

Porém, a nível macrorregional, este programa planificou obras que passaram a ser executadas a partir da década de 1960, como diversas bases de observação dos níveis d'água e três barragens que minimizariam as cheias: a de Ituporanga, com 97.510.000 metros cúbicos e a de Taió com 110.960.000 metros cúbicos de capacidade e a represa do Rio Hercílio, com 253.000.000 metros cúbicos, sendo que esta última não beneficiaria a cidade de Rio do Sul. ${ }^{23}$

Após a enchente de 1969, quando "os municípios do Alto Vale também [...] foram atingidos. As barragens, em construção estavam, certamente, fazendo falta". ${ }^{24}$ Rio do Sul, como as outras comunidades do Vale do Itajaí, que sempre sofriam com as enchentes, esperava que a conclusão das barragens propostas pelo DNOS, viesse em direção a tranquilidade total, como descreve parte do Relatório das Enchentes de 1983:

Confiante na ação protetora das barragens Sul e Oeste, respectivamente localizadas nos municípios de Ituporanga e Taió, e já desacostumada a conviver com o flagelo das cheias, a população riosulense foi apanhada de surpresa, 
haja vista que, se nas enchentes anteriores somente as zonas ribeirinhas eram atingidas, desta feita todo o centro da cidade ficou submerso, para perplexidade e desespero da população $[\ldots] . .^{25}$

A população de Rio do Sul esperava das barragens a solução das enchentes que assolavam a cidade, mas não foi o que ocorreu, já que os limites físicos, dentro de condições pré-definidas, causam uma falsa sensação de segurança, pois podem, em certos casos, aumentar o número e o volume das enchentes. Além do mais, as barragens, amortecem a cheia à jusante, mas não tem a função de eliminar as enchentes, como é costumeiramente apregoado.

$\mathrm{O}$ aumento populacional, bastante acentuado até meados dos anos 1970, não foi acompanhado de uma gestão adequada das áreas de risco. A segurança propiciada pelas equivocadas avaliações em relação àquelas obras estruturais, levou os riosulenses a ignorar a possibilidade das cheias. Desta forma, enquanto o centro comercial de Rio do Sul deslocou-se, fixando-se em locais, a princípio, não inundáveis; na periferia, a convivência com alagamentos acomodou a população e muitos, negligenciaram a lembrança, não recorrendo a memória e esqueceram das enchentes, erguendo suas casas em lotes nas áreas alagáveis indicadas pelo mapa, desenhado, na década de 1930, por Gino de Lotto $^{26}$, principalmente as perto do centro, com anuência do poder público, como se o problema das enchentes fossem coisa do passado. Como resultado, quando da catastrófica enchente de 1983, Rio do Sul apresentava alta densidade demográfica instalada nas áreas alagáveis.

Infelizmente para a maioria das pessoas a memória sobre os desastres tem curta duração. No caso das enchentes, por exemplo, assim que as águas retornam a seus níveis normais e as vitimas se recuperam e também desaparece o interesse da mídia. As vitimas diretamente afetadas não esquecem tão rapidamente, mas com o tempo a memória também se esvai. ${ }^{27}$

Esta ocupação das áreas de risco, ao longo dos anos, provavelmente interferiu na condição natural dos rios. O processo de desenvolvimento econômico e o modelo que atendeu a este padrão de ocupação do espaço geográfico e de utilização dos recursos ambientais sobrecarregou a capacidade regenerativa e assimilativa do ambiente, preparando um desastre ambiental de grandes proporções.

Esta catástrofe anunciada chegou em 1983, não só de forma descomunal, mas também, inusitadamente recorrente, ocorrendo duas no mesmo ano em julho e em agosto e mais uma no ano de 1984. A enchente de julho de 1983 foi a maior da história de Rio do Sul, tendo o Rio Itajaí-Açu atingido a cota de 15,08 metros, registrando na Rua Carlos Gomes, no centro da cidade, aproximadamente três metros a mais do que qualquer cota de enchente anterior, sendo, mesmo considerando o nível oficial de 13 metros, fantástica e inacreditável (Figura 4). O saldo final foi de 4 mortes e um rastro de 
destruição que alcançou repercussão nacional, sendo considerada a Enchente do Século. ${ }^{28} \mathrm{O}$ impacto causado por estas enchentes suplantou a capacidade de processamento político do problema.

\section{Figura 4 - Foto da vista parcial da Rua XV de Novembro no Bairro Laranjeiras em Rio do Sul (Enchente de 1983)}

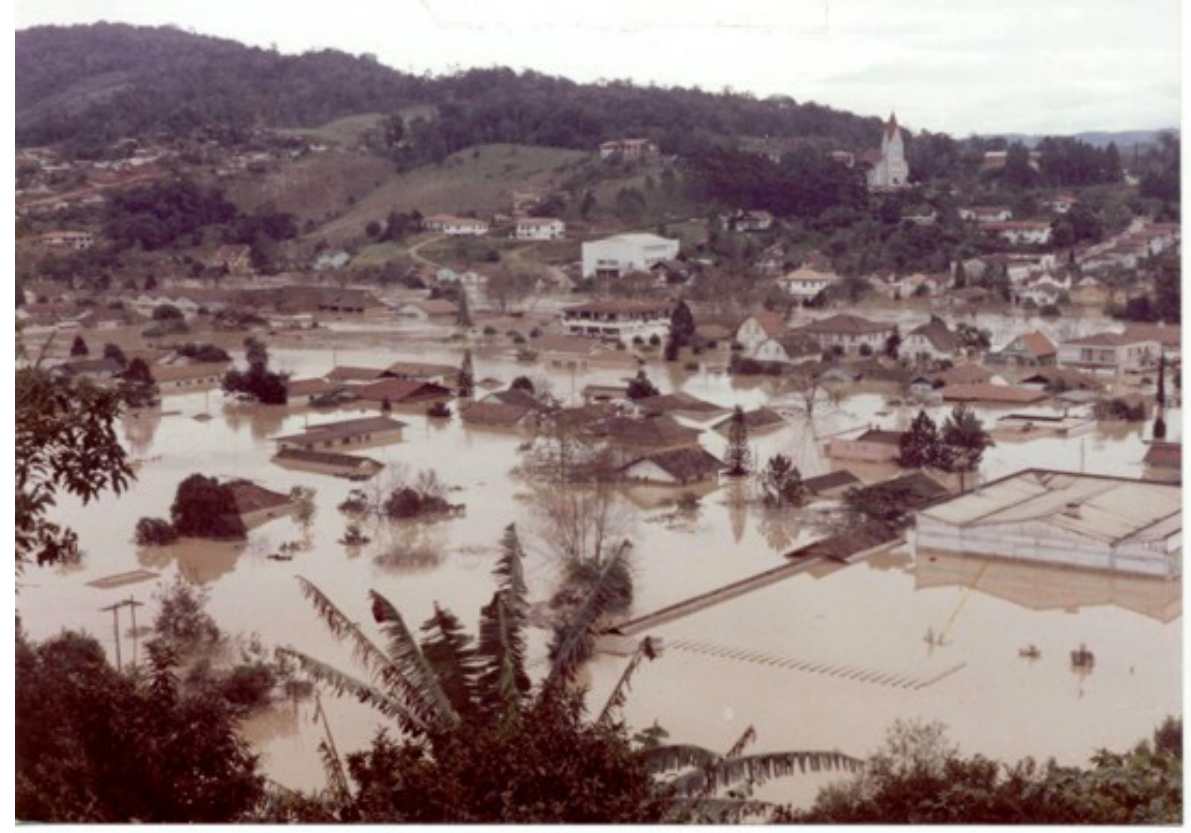

Fonte: Arquivo Particular Guthis Auto Peças. Disponível em: <http://www. guthsautopecas.com.br/fotos2enc.html>. Acesso em 23 mar. 2014.

A enchente de julho de 1983, inicialmente, castigou a periferia e terminou atingindo o centro urbano, prejudicando todas as classes sociais; dos pobres residentes na beira do rio aos ricos das áreas urbanas mais valorizadas.

A área urbana de Rio do Sul atingida foi extremamente maior do que a que se tinha como última referência, que era a enchente de 1954. Das 1664 residências atingidas, 259 acabaram sendo destruídas, 380 semidestruídas, 138 tiveram suas estruturas abaladas e das 125 indústrias existentes, 120 foram atingidas. Durante semanas, a cidade ficou isolada e apavorada com a possibilidade do rompimento das barragens à montante, faltou água e luz $\mathrm{e}$ 25.000 mil pessoas ficaram flageladas. ${ }^{29}$

Através do Decreto Estadual $n^{\circ}$ 065/83, de 08.07.83, determinou-se "Estado de Emergência" seguido, após quatro dias, do decreto no 070/83 de "Calamidade Pública", em razão do aumento da gravidade da situação. O abalo sofrido pela cidade gerou comoção em todo o país, recebendo a cidade de Rio 
do Sul e a região do Alto Vale do Itajaí, atenção da mídia nacional assim como a solidariedade nacional e internacional.

Quando a situação começava a ser controlada, sobreveio uma segunda cheia, que registrou a segunda maior cota d'água da história riosulense, com o nível de 10,80 metros. $^{30} \mathrm{~A}$ tragédia só não foi maior porque, desta vez, a Prefeitura e a Defesa Civil municipais foram informadas com antecedência pelo DNOS, podendo orientar a população. O prejuízo financeiro total pelas duas enchentes chegou ao montante de Cr\$ 19.095.708.000,00, correspondentes, na época, a US\$ 1,1 bilhão. ${ }^{31}$

Enquanto, no evento de 1983, o desastre foi resultante de uma longa precipitação de 15 dias, perfazendo o total de $400 \mathrm{~mm}$, em 1984 a chuva foi rápida, durou apenas 2 dias, porém registraram-se $200 \mathrm{~mm}$ de precipitação. A destruição foi menor que no ano anterior, mas foi considerável, aumentando o medo e a capacidade de resiliência da população.

Com tais inundações expressivas, duradouras e sucessivas, romperamse os ritmos de atividades econômicas e cotidianas da população, já abaladas pela recessão da economia, em baixa devido ao fim do ciclo da madeira.

Após os desastres, foi preciso reconstruir a cidade, cobrar ações das autoridades, adaptar-se à nova situação, ou mudar de residência, ou de cidade. Os serviços de limpeza, recuperação e levantamento de prejuízos, duraram meses. Em meio a tanta desgraça, parecia ser impossível a reconstrução.

Quando da tragédia de 1983, a Defesa Civil local foi montada às pressas; não dispunha de pessoal e equipamentos capazes de atender às necessidades de tantos atingidos. As obras de contenção dirigiram-se à atividades de reconstrução. Foram buscadas soluções nos âmbitos federal, estadual e municipal, objetivando a elaboração de obras que visassem a eliminação ou minimização do problema das enchentes. Em julho de 1983, foi instituído o Programa Especial de Reconstrução do estado de Santa Catarina pela Lei ${ }^{\circ}$ 6.256 de 26/07/1983 e o Conselho de Reconstrução. Após a terceira enchente, em dezembro de 1984, foi redigido um Plano Global e Integrado de Defesa contra as enchentes, aprovado pelo Conselho Extraordinário de Reconstrução, na forma da resolução $\mathrm{n}^{\circ} 30 / 85$, o qual nunca foi implantado. ${ }^{32}$

Em 1986 foi lançado o Projeto JICA - The Itajai River Basin Flood

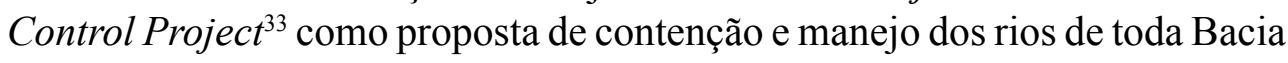
do Rio Itajaí-Açu. O projeto apresentou desconhecimento da dinâmica dos rios que formam a Bacia do Rio Itajaí-Açu, assim como dos impactos ambientais a ele associados. Além do mais, o referido projeto não foi executado na época, em função da indisponibilidade financeira e da extinção do DNOS em 1990.

Somente na década seguinte foi lançado o Plano Global e Integrado de Defesa contra Enchentes - Ecossistema Bacia do Rio Itajaí-Açu, ou PLADE ${ }^{34}$, elaborado pelo governo estadual (1991-1994), a partir do Projeto JICA, que visava à obtenção de recursos externos para viabilização deste, destarte todas 
as suas insuficiências, sobressaindo-se obras estruturais, como alargamento dos rios e melhorias da calha. Este Plano acabou por ser adiado, também por falta de recursos; somente após a enchente de 2008, algumas das obras nele previstas voltaram a ser colocadas em prática.

Como no passado, apesar dos prejuízos e danos gerados pelos desastres ambientais, as providências para seu tratamento permaneceram marginalizadas na agenda de prioridades do governo estadual, só recebendo atenção nos momentos de emergência. Já no âmbito municipal, as ações voltaram-se à reconstrução e, finalmente, foi implantado um departamento de Defesa Civil.

Assim, Rio do Sul, como quase todo o restante do Vale do rio Itajaí, com exceção de Blumenau, encontrava-se novamente despreparado para os novos desastres e flagelos que sobrevieram em 1997, 1998, 2008, 2009, 2011 e 2013.

As duas primeiras não trouxeram grandes estragos à cidade de Rio do Sul, embora tenham levado ao desabrigo muitos dos habitantes das margens, como "as 18 famílias que moravam às margens do Rio Itajaí do Oeste e ficaram desabrigadas após as enchentes"35, de 1998. Mas, as enchentes de 2011 à atingiram em cheio.

No desastre de 2011, o nível dos rios atingiu 12,98 metros, 15 mil pessoas foram desalojadas, sendo que 3.000 foram desabrigadas. ${ }^{36}$

A mesma reportagem, do jornal Diário do Alto Vale, de 10 de setembro de 2013, trazia boas notícias para Rio do Sul, pronunciadas pelo Prefeito Garibaldi Antônio Ayroso, anunciando a breve construção de novas obras contra enchentes previstas pelo Plano de Aceleração Econômica (PAC), do governo federal.

Serão feitas as ações de aumento do nível das barragens de Taió e Ituporanga, além de mais cinco pequenas represas que serão feitas e irão atingir e vão atingir positivamente Rio do Sul. Para a capital do Alto Vale, diretamente vai ser feito o desassoreamento do rio Itajaí-Açú graças ao governo federal e estadual. Logo começam os trabalhos no rio, agora neste mês ainda, vai ser feita a limpeza do rio e a reestruturação das encostas que vão evitar problemas com enchentes. ${ }^{37}$

Esperava-se, ainda, outras medidas posteriores, de cunho não estrutural, por meio de:

[...] um plano de ação organizado com as associações de bairros e a ideia é fazer chegar a informação correta para toda a população. Não podemos ser desorganizados, se a população sabe o que deve fazer em momentos como esses, os prejuízos são muito menores. ${ }^{38}$ 
Assim, não se esperava, nem mesmo com o retorno de chuvas, que contavam com previsão de atingirem $172 \mathrm{~mm}$, para os dias entre $20 \mathrm{e}$ 22/09/2013, nenhuma enchente de maiores proporções, como expressa da seguinte forma o mesmo periódico, no dia 20 de setembro:

[...] a possibilidade de uma enchente de grande porte está descartada, pois as barragens Oeste (Taió) e Sul (Ituporanga) estão operante em nível normal, mas os moradores das áreas mais baixas do município devem ficar alerta. A Defesa Civil deverá tomar medidas a partir de hoje, deixando o departamento e a Secretaria de Obras de sobreaviso caso as previsões se confirmem. ${ }^{39}$

Sendo que, as regiões da cidade que mais preocupavam eram:

Os bairros, Pamplona, Bela Aliança, Barra do Trombudo, Budage Canoas [Figura 5] [que] geram maiores preocupações à Defesa Civil, porque há alguns locais com pontos de alagamento e também pode haver movimentações de terra nestas áreas. ${ }^{40}$

\section{Figura 5 - Foto vista parcial do Bairro Canoas na enchente de novembro de 2013}

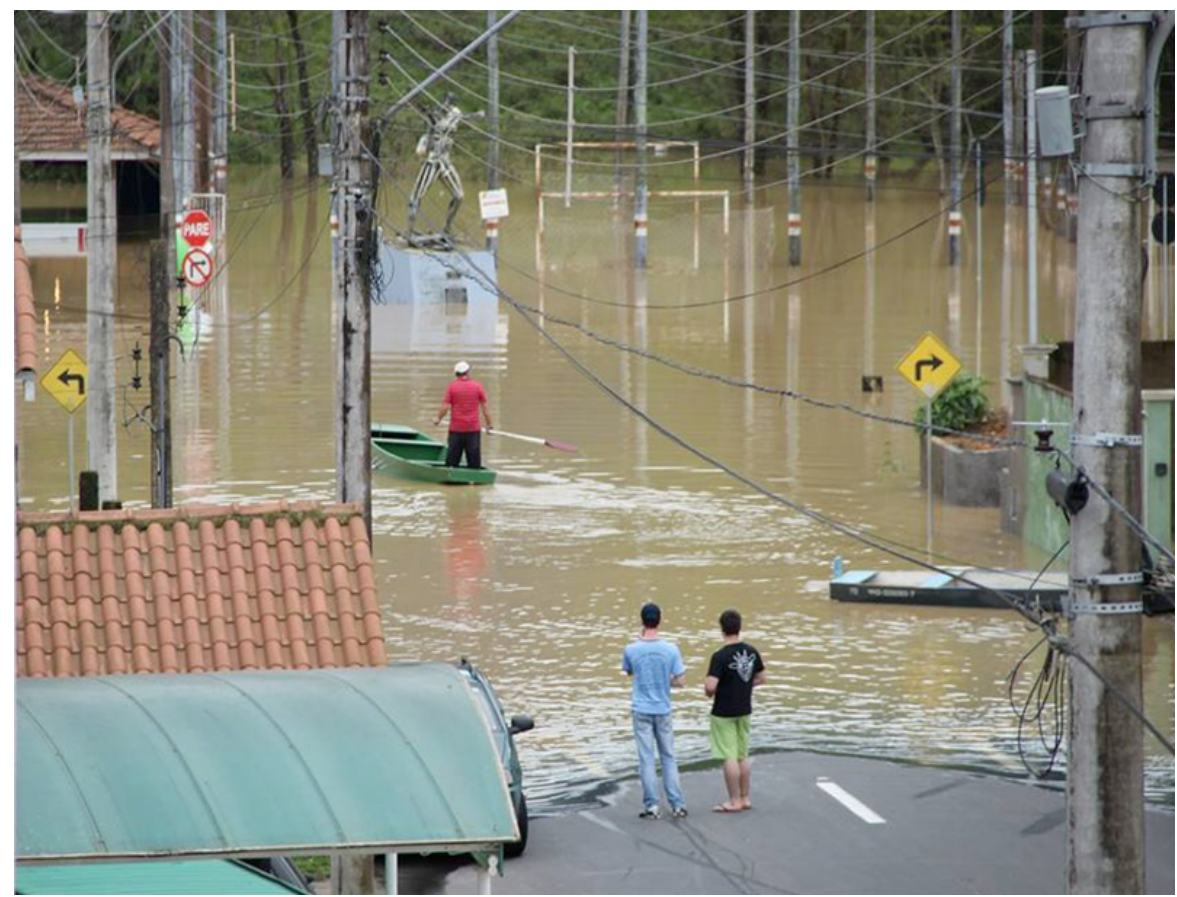

Fonte: Jornal Alto Vale Notícias, 21, 22 e 23 ago. 2013, ano 01, edição 166. 
Segundo o Jornal A Cidade, de Rio do Sul.

A Secretaria de Assistência Social e da Habitação contabilizou 320 famílias desabrigadas, cerca de 1 mil pessoas. Ao total, 410 atendidas nos 13 abrigos disponibilizados pela Defesa Civil do Município. ${ }^{41}$

De acordo com o mesmo jornal, 70 localidades ficaram sem luz elétrica, uma adutora de água rompeu-se e o piso térreo da Delegacia Regional de Polícia Civil foi evacuado.

Já o jornal Alto Vale Notícias divulgou o número de:

[...] mais de 6 mil pessoas desalojadas, e outras 1.080 moradores desabrigadas. [...] Na quinta feira (25), o Rio Itajaí-Açú, atingiu 7,80 metros na medição às $11 \mathrm{~h}$, mas para o nível voltar ao normal ainda precisa baixar mais de 1,50 metros. $^{42}$

Figura 6 - Foto aérea da cidade de Rio do Sul (Enchente de 2013)

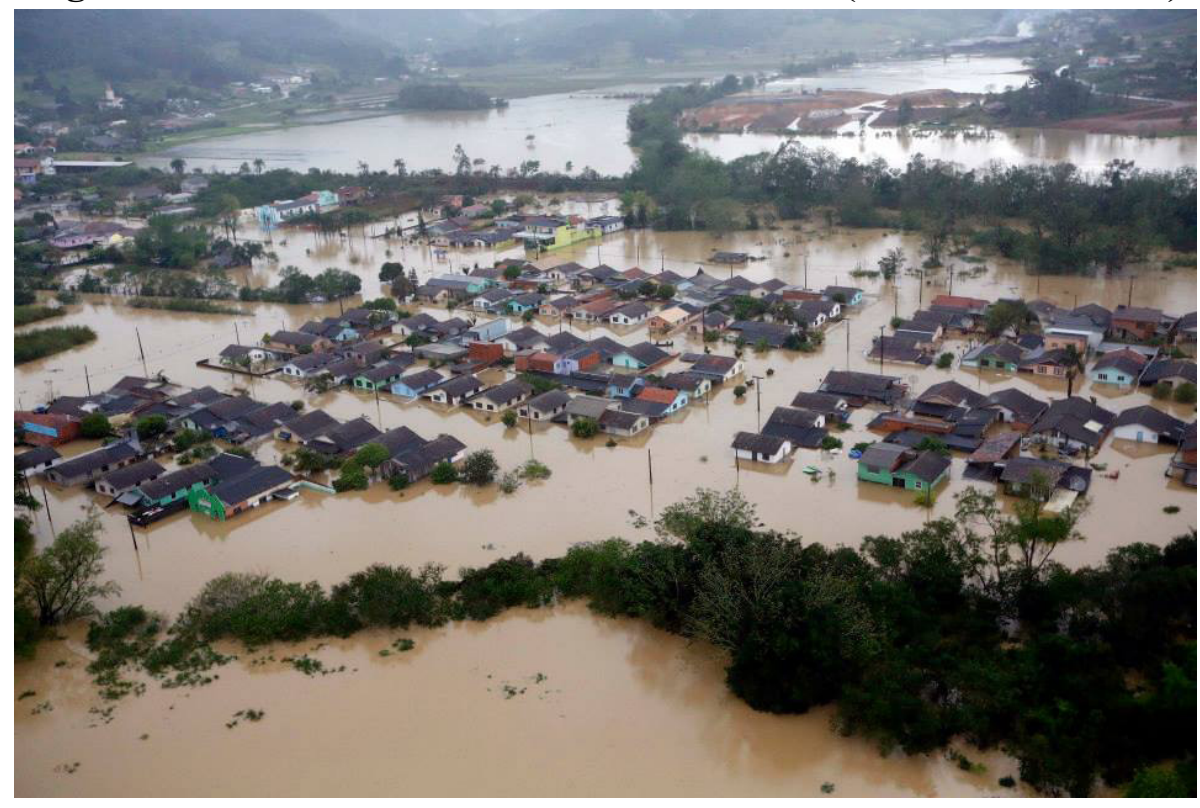

Fonte: Jornal Alto Vale Notícias, 21, 22 e 23 ago. 2013, ano 01, edição 166.

A decretação do Estado de Calamidade Pública, no dia 25 de setembro, garantiu a ação da Defesa Civil, das Polícias, dos Bombeiros e da Prefeitura, para a remoção e abrigo dos flagelados e 
[...] na recuperação dos prejuízos da forma mais ágil possível para o atendimento emergencial às pessoas afetadas pela chuva. Os órgãos de Defesa Civil e a Prefeitura poderão comprar, sem o processo burocrático de concorrência pública, remédios, alimentos, equipamentos e utensílios domésticos e contratar máquinas para tirar bloqueio nas estradas. $^{43}$

O Governo Federal, novamente, lançou um programa de obras para evitar novos eventos:

Na ocasião, [o ministro da Integração Nacional] Fernando Bezerra garantiu que o Governo Federal já estabeleceu uma parceria com o Governo do Estado que soma quase $\mathrm{R} \$ 1$ bilhão em ações de prevenção às cheias. $\mathrm{O}$ ministro informou que nas próximas semanas serão lançadas as ordens de serviço para parte dessas obras. ${ }^{44}$

O Jornal Riosulense afirma que, os prejuízos seriam maiores na ausência das "previsões de $300 \mathrm{~mm}$ de chuva para o fim de semana" 45 , o que indica que, desta vez, pelo menos, os dispositivos de alerta possibilitaram, à população e às autoridades, prevenirem-se contra o desastre ambiental.

Enfim, nesta última enchente que assolou Rio do Sul, no que pese a melhoria de certos dispositivos de prevenção e defesa contra este fenômeno, como a previsão acertada e antecipada do volume das precipitações e a ação suficiente de uma Defesa Civil já preparada, o processo que levou ao desastre continuou respondendo ao mesmo padrão dos eventos anteriores: confiança demasiada nos dispositivos existentes e a serem providenciados, conjugado à falta de cuidado na relação com o meio ambiente; deflagração e desenrolar do desastre, mesmo que com respostas mais efetivas das autoridades locais; milhares de flagelados, desalojados e demais prejudicados e; novamente, promessas governamentais de ações ágeis no momento de emergência, quando, nos momentos de "normalidade", as providências planejadas eram realizadas morosamente, como reclamou o Deputado Estadual Jailson Lima, do Partido dos Trabalhadores (PT), que:

[...] voltou ao assunto e criticou a lentidão do governo em executar obras de prevenção, cujos recursos, originários do governo federal, estão disponíveis, porém não foram gastos integralmente. Segundo o representante de Rio do Sul, há R \$ 700 milhões disponíveis para obras de contenção. Ele citou o caso do sistema de monitoramento, cujos recursos na ordem de R $\$ 25$ milhões foram liberados, todavia o sistema 
ainda não foi implantado [...] [e] também criticou os editais das barragens de Taió e Ituporanga. [...] [que] não era claro, tinha restrições a empresas e uma delas, de Ituporanga, entrou com uma ação e o juiz trancou o processo. ${ }^{46}$

Vale ressaltar a ação da Defesa Civil, amparada numa das mais completas legislações do mundo, que, uma vez respeitada; e o foi, no caso de Rio do Sul, somente após as enchentes de 2008, como vimos; garante que a Defesa Civil se organize em sistemas abertos com a participação dos governos locais e da população no desencadeamento das ações preventivas e de resposta aos desastres. Pela ação da Defesa Civil e devido às previsões antecipadas sobre as chuvas que permitiram uma maior eficácia de seu trabalho preventivo, o desastre de 2013 teve proporções minoradas em relação aos anteriores.

\section{CONSIDERAÇÕES FINAIS}

As enchentes são um problema histórico que atinge as populações dessa região. No entanto, em que pesem os riscos desta situação para os habitantes das cidades e comunidades ribeirinhas, esses desastres periódicos não têm se constituído em empecilho capaz de desestabilizar permanentemente a economia da região. Um fato a ser salientado, é que as circunstâncias e efeitos das enchentes se desenvolvem de formas diferenciadas em cada uma das quatro sub-regiões que apresentam algumas características ambientais distintivas as quais conformam o vale do rio Itajaí-Açu, o que deve ser levado em conta, quando da realização de estudos, planejamento e execução de obras para contenção das cheias.

As grandes enchentes, que assolam o Município de Rio do Sul, desde a época em que, o mesmo, ainda era constituído como Distrito, associado à Blumenau, respondem a um padrão exaustivamente repetitivo, por não serem tomadas as devidas providências necessárias pelo Estado, por meio de Políticas Públicas céleres e adequadas.

Consequentemente, a maioria das obras realizadas pelo mesmo, até então; não têm logrado êxito às contenções destes desastres ambientais, fazendo com que a situação se torne cada vez mais alarmante.

É certo que, tais fatores, já vêm de longa data, desde a ocupação da região, onde o solo foi utilizado de forma incorreta, o que só fez agravar o equilíbrio ambiental de maneira generalizada. Reforçando esta situação, mais recentemente, as enchentes foram estimulo para uma ocupação desordenada do solo urbano, valorizando o solo em algumas áreas e desvalorizando-o em outras. O que causou um processo de fuga das atividades urbanas para além dos 
supostos limites das cotas das enchentes, proporcionando uma irreal impressão de crescimento e desenvolvimento.

Deve-se levar em conta que a memória sobre as enchentes desvanece quando ocorrem longos períodos de ausência de enchentes de grande porte. Como aqui observado, no caso de Rio do Sul, no período entre 1953/54 e 1983, a população e as instituições municipais logo deixaram de perceber o risco inerente das enchentes, ignorando um melhor planejamento sobre eles.

Esta totalidade de acontecimentos, nesses longos anos, contribuíram e muito para a recorrência das enchentes; porém, há de focar-se também, nas Políticas Públicas de igual modo, por deixarem a desejar, em corolário referente às obras que deveriam ser corretamente realizadas, podendo, assim, conter as enchentes.

Em decorrência de diversos fatores não há uma regularidade na atenção a possibilidade de enchentes fora dos períodos emergenciais, mantendo-se insolúvel o óbice, principalmente devido a: desconhecimento dos planejadores sobre medidas de controle de enchentes; desorganização estatal no gerenciamento de medidas relativas a enchentes; pequena produção científica sobre o assunto; maior aplicabilidade de programas de orientação educacional da população sobre o controle de enchentes, percepção de riscos, desastres e de implantação de obras não estruturais para contenção de enchentes.

É verdade que as barragens e, depois, as demais medidas e intervenções estruturais e não estruturais tiveram efeito minimizador dos desastres, mas a lentidão tornou-se sempre a tônica, quando a situação emergencial foi contornada e voltou-se a normalidade. Desta forma, algumas obras com financiamento liberado pelo Governo Federal continuam não iniciadas ou inacabadas.

\section{NOTAS}

1 O Projeto Capes PRODOC Desastres Ambientais e Políticas Públicas em Santa Catarina está sendo Desenvolvido pela área de concentração Sociedade e Meio Ambiente do Programa de Pós-Graduação Interdisciplinar em Ciências Humanas da UFSC (PGICH-UFSC), sob a coordenação da Prof. Dr ${ }^{\mathrm{a}}$ Eunice Sueli Nodari e tem como objetivo discutir os desastres ambientais e avaliar as Políticas Públicas, e/ou outras ações governamentais frente aos eventos drásticos que têm atingido este Estado no século XIX, XX e início do XXI.

2 FRANK, Beate; SEVEGNANI, Lúcia. Desastre de 2008 no Vale do Itajaí: água, gente e política. Blumenau: Agência de Água do Vale do Itajaí, 2009. p. 24.

3 Ibidem, p. 28

4 KLEIN, Roberto Miguel. Ecologia da flora e vegetação do Vale do Itajaí. Sellowia. Anais Botânicos do Herbário “Barbosa Rodrigues”, Itajaí, v. 31, 1979. 
5 POLEZA, Maristela Macedo. Mudanças na estrutura urbana de Rio do Sul em decorrência das enchentes de 1983. Dissertação (Mestrado) - Programa de Mestrado em Desenvolvimento Regional, Universidade Regional de Blumenau, Blumenau, 1997. p. 33.

6 Ibidem.

7 Ibidem.

8 O DNOS foi um órgão federal criado para fomentar e coordenar ações infraestruturais, realizou poucas ações práticas neste sentido. Entre os anos de 1967 e 1985 a instituição concretizou, na região em questão, apenas a construção de poucas obras estruturais, como a barragem de Taió (1973), para conter a vazão do Rio Itajaí D’Oeste; a barragem de Ituporanga (1976), que represa as águas do Rio Itajaí do Sul e; a barragem de José Boiteux, com objetivo de controlar o fluxo do Rio Hercílio, concluída somente em 1992.

9 MELLO, Flavio Miguez de. (Coord.). A história das barragens no Brasil: Séculos XIX, XX e XXI. Cinquenta anos do Comitê Brasileiro de Barragens. Rio de Janeiro: CBDB, 2011. p. 157.

${ }^{10}$ NÖTZOLD, Ana Lúcia Vulfe; VIEIRA, Edna Elza. A ocupação do espaço. In: KLUG, João; DIRKSEN, Valberto. Rio do Sul: uma historia. Rio do Sul: Fundação Cultural de Rio do Sul, 1999. p. 18-34.

${ }^{11}$ POLEZA, op. cit., p. 10.

12 Ibidem, p. 33.

${ }^{13}$ FUNDAÇÃO UNIVERSIDADE REGIONAL DE BLUMENAU. Centro de Operação do Sistema de Alerta (CEOPS). Picos de Enchentes Registrados na Bacia do Rio Itajaí-Açú. Disponível em: $<$ http://ceops.furb.br/index.php?option=com_wrapper\&view=wrapper\&Ite mid=42>. Acesso em: 23 mar. 2014.

14 Jornal A República, 02 out. 1928, n. 3, p. 2.

15 Jornal A República, 02 out. 1918, n. 3, p. 2.

${ }^{16}$ CARDOSO, Alfredo Emanoel. Compêndio histórico e geográfico de Rio do Sul. $2^{\mathrm{a}}$ ed. Rio Do Sul, 1991. p. 50.

${ }^{17}$ PELUSO, 1942, apud POLEZA, op. cit., p. 48.

${ }^{18}$ SILVA, José Ferreira. Blumenau em Cadernos. Blumenau, tomo XVI, n. 1, p. 16, jan. 1975.

${ }^{19}$ Ibidem.

${ }^{20}$ Arquivo Particular Guths Auto Peças. Disponível em: <http://www.guthsautopecas.com.br/ fotos2enc.html>. Acesso em: 23 mar. 2014.

${ }^{21}$ SILVA, op. cit., p. 16.

${ }^{22}$ Ibidem.

${ }^{23}$ CARDOSO, op. cit., p. 50-52.

${ }^{24}$ SILVA, op. cit., p. 16.

${ }^{25}$ RIO DO SUL. Prefeitura Municipal. Relatório das enchentes de julho de 1983. Arquivo Histórico de Rio do Sul, p. 02. Mimeografado.

${ }^{26}$ Gino Alberto de Lotto foi um engenheiro italiano, radicado em Rio do Sul no período pósguerra, responsável pelo Plano Regulador e Mapa Cadastral de Rio do Sul, além de outras 
obras, como a Catedral de São João Batista, o Colégio Maria Auxiliadora, as pontes Curt Hering e dos Arcos (POLEZA, op. cit., p. 55).

${ }^{27}$ MAUCH, C.; PFISTER, C. (Orgs.). Natural Disasters, Cultural Responses: case studies toward a global environmental history. Lanham: Lexington, 2009. p. 3.

${ }^{28}$ Descrita em prosa "Tragédia”, do Dr. Juarez Leandro Eiras e verso: “Inundação do Sul do Brasil”, de Vândio Marcelino Barbosa. Arquivo Histórico de Rio do Sul.

${ }^{29}$ RIO DO SUL, op. cit., p. 3.

${ }^{30}$ Ibidem, p. 4.

${ }^{31}$ Ibidem, p. 6.

${ }^{32}$ LINS, H. N.; LISBOA, A. M. Plano Global e Integrado de Defesa Contra Enchentes. Ecossistema Bacia Hidrográfica do Rio Itajaí-Açu: Aspectos Econômicos do PLADE. In: Dynamis - Revista de Divulgação Cultural, Blumenau: Ed. da FURB, v. 2, n. 8, p. 151-163, jul./set. 1994.

${ }^{33}$ JAPAN INTERNATIONAL COOPERATION AGENCY - JICA. Final report on the Itajai River basin flood control project - Part I. Tokyo, 1988, 95 p.

${ }^{34}$ LINS, H. N.; LISBOA, A. M. op. cit., p. 151-163.

35 Jornal de Santa Catarina, 7 maio 1999, p. 7B.

${ }^{36}$ Jornal Diário do Alto Vale, Rio do Sul, 10 set. 2013, Caderno Especial, p. 10.

${ }^{37}$ Ibidem.

${ }^{38}$ Ibidem

${ }^{39}$ Jornal Diário do Alto Vale, Rio do Sul, 20 set. 2013, p. 14.

${ }^{40}$ Ibidem.

${ }^{41}$ Jornal A Cidade, 27 set. 2013, Caderno Enchentes, p. 5.

${ }^{42}$ Jornal Alto Vale Notícias, 27 set. 2013, p. 5

${ }^{43}$ Jornal O Riossulense, 27 set. 2013, p. 7.

${ }^{44}$ Ibidem.

${ }^{45}$ Ibidem, p. 16.

${ }^{46}$ Jornal A Cidade, 27 set. 2013, Caderno Enchentes, p. 17. 